\title{
Investigation of Antimicrobial Activity of Lallemantia canescens (L) Fisch \& Mey.
}

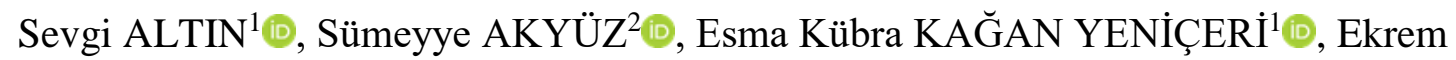

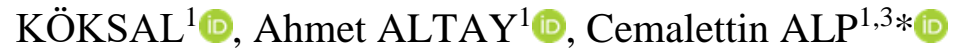

\author{
Erzincan Binali Yıldırım University, Faculty of Arts and Science, Chemistry Department, Erzincan / \\ TURKEY \\ ${ }^{2}$ Erzincan Binali Yıldırım University, Faculty of Medicine, Department of Medical Microbiology, Erzincan / \\ TURKEY \\ ${ }^{3}$ Erzincan Binali Yıldırım University, Çayırlı Vocational School, Department of Medical Services and \\ Techniques, Medicinal Laboratory Techniques, Erzincan / TURKEY
}

Geliş / Received: 10/08/2021, Kabul / Accepted: 31/08/2021

\begin{abstract}
Studies on the lethal effects of plants on harmful microorganisms have made them an important and valuable resource for health. Turkey, wherefore the junction center of three phytogeographic regions, is home to numerous medicinal and aromatic plants with its rich flora. In this study, antimicrobial activity of hexane, ethylacetate, methanol and water extracts of aerial parts of L. canescens, which has known as "Topajdarbaşı" in Turkey, was investigated. Plant samples were collected from Pöske Mount in Erzincan. Antimicrobial activities of extracts were evaluated using disc diffusion method against Gram-negative bacterias (Pseudomonas aeruginosa, Klebsiella pneumoniae, colistin-resistant Escherichia coli, Escherichia coli) and Gram-positive bacterias (Enterococcus faecalis, Staphylococcus aureus, Streptococcus pneumoniae). To conclude, hexane, ethylacetate and methanol extracts of $L$. canescens showed considerable antimicrobial activity against $S$.aureus, E.faecalis, S.pneumoniae strains.
\end{abstract}

Keywords: Lamiaceae, Lallemantia canescens, antimicrobial activity, disc diffusion

\section{Lallemantia canescens (L) Fisch \& Mey. Bitkisinin Antimikrobiyal Aktivitesinin Araştırılması}

\section{$\ddot{\mathbf{O} z}$}

Bitkilerin zararlı mikroorganizmaları öldürücü etkileri ile ilgili yapılan çalışmalar onların sağlık açısından önemli ve değerli bir kaynak haline gelmelerini sağlamıştır. Türkiye üç fitocoğrafik bölgenin birleşim merkezi olmasından dolayı zengin florasıyla sayısız tıbbi ve aromatik bitkiye ev sahipliği yapmaktadır. Bu çalışmada Türkiye'de “Topajdarbaşı” olarak bilinen L. canescens bitkisinin toprak üstü kısımlarının hekzan, etilasetat, metanol ve su ekstrelerinin antimikrobiyal aktivitesi araştırılmıştır. Bitki örnekleri Erzincan İli Pöske Dağı bölgesinden toplanmıştır. Ekstraktların antimikrobiyal aktiviteleri; standart Gram negatif bakterilere (Pseudomonas aeruginosa, Klebsiella pneumoniae, kolistin dirençli Escherichia coli, Escherichia coli) ve standart Gram pozitif bakterilere (Enterococcus faecalis, Staphylococcus aureus, Streptococcus pneumoniae) karş1 Kirby-Bauer disk difüzyon yöntemi ile belirlenmiştir. L. Canescens'in hekzan, etilasetat ve metanol ekstreleri S. aureus, E. faecalis, S. pneumoniae suşlarına karşı antimikrobiyal aktivite göstermiştir.

Anahtar Kelimeler: Lamiaceae, Lallemantia canescens, antimikrobiyal aktivite, disk difüzyon

*Corresponding Author: calp@erzican.edu.tr 


\section{Introduction}

Lamiaceae, known as Labiatae or the Turkish name Ballibabagiller family, is one of the largest families, with about 236 genera and around 7173 taxa, distributed worldwide, especially in the temperate zone (Harley et al., 2004, Jamzad et al., 2003, Li et al., 2016). Among 167 families in our country, Lamiaceae family ranks fourth with its 586 species content, while it ranks third among endemic species. (Güner et al., 2012).

They attract attention with their pleasant smell and colorful flowers besides herbaceous, rarely tree, bush or semi-bush, and ivy structures. (Harley et al., 2004). According to their pollen morphologies, they were collected in two subfamilies as Lamioideae and Nepetoideae (Erdtman, 1945). In the Flora of Turkey, the Lamiaceae family is described with 45 genera, 565 species and 735 taxa. The taxa that make up the family are classified into 5 subfamilies; Ajugoideae, Lamioideae, Nepetoideae, Scitellorioideae, Teucrioideae (Hedge, 1986). The genus Lallemantia, which is the subject of this study, is defined in the group Nepetoideae (Erdtman, 1945). Some members of the Lamiaceae family have been used as folk medicine in various parts of the world. Due to the essential oils they contain, these species have a wide range of industrial uses, including the cosmetics, perfumery, food and pharmacology. In addition, many species are also used as ornamental plants (Baytop, 1991; Davis et al., 1988; Seçmen et al.,1989; Tutin et al.,1972).

Lallemantia, defined as Ajdarbaş1, is a genus of Lamiaceae family, spreading from Turkey to the Himalayas, with bright blue flowers and a pleasant scent (Baytop, 1999; Li et al.,1994; Harley et al., 2004). Three of the Lallemantia family (L. Peltata, L. Royleana, L. Iberica, L. Canescens, L. Baldschuanica), which has 5 species in the world, are grown in Turkey. (Davis et al., 1988). Lallemantia species have important biological functions, some of which are listed as follows: antimicrobial, antifungal, diuretic, diuretic, expectorant, used in the treatment of cough, stomach and abdominal pain (Rivera et al., 1992, Ersoy, 2009). In addition, they show strong antioxidant properties due to their high flavonoid and phenolic content. (Keskin, 2014).

Due to the negative side effects of synthetic drugs, which are currently used in the treatment of many diseases in metabolism and especially because they create significant resistance to antibiotics, scientists have directed their studies to research the natural-sourced drugs (MortezaSemnani, 2006).

Lallemantia canescens, which is the subject of our study, is one of the three species of the genus Lallemantia grown in Turkey. This species, also known as Topajdarbaş1, has spread over a wide geography including Armenia, Azerbaijan, Iran and Turkey (Erdoğan and Everest, 2013, Dinç et al., 2009). A rare number of studies have been found in the literature, except for morphological studies of the related species (Erdoğan and Everest, 2013, Dinç et al., 2009).

Studies with different species of the Lallemantia plant have shown that these species have high antimicrobial and antioxidant activity because of their high secondary metabolite contents. On the other hand, there is no study in the literature on the antimicrobial activity of L. canescens, which grows abundantly in our region. In this study, it is aimed to fill the gap in the literature by comparatively examining the antimicrobial activities of water (LCS), methanol (LCM), hexane $(\mathrm{LCH})$ and ethanol (LCE) extracts obtained from the aerial parts of the L. canescens (LC) plant on 7 standard bacterial isolates. 


\section{Material and Methods}

\subsection{Plant Material}

L. canescens species used in the study was collected from the Pöske Mountain location of Erzincan province in July 2019. The samples were collected by Prof. Dr. Ali Kandemir (Erzincan Binali Yıldırım University, Department of Biology). It was identified by Kandemir and stored in Erzincan Binali Y1ldırım University Herbarium with collector number A. Kandemir 5490.

\subsection{Plant Extraction}

The aerial parts of the plant, which was dried at room temperature with a ventilation system and out of the sun, were crushed with liquid nitrogen and turned into powder. The powdered sample (100 g) was extracted with hexane, ethylacetate, methanol and water, respectively, according to increasing polarity. The solvents were evaporated to obtain $0.93 \mathrm{~g}$ of hexane extract, $2.69 \mathrm{~g}$ of ethyl acetate extract, $3.44 \mathrm{~g}$ of methanol extract and $3.47 \mathrm{~g}$ of water extract.

\subsection{Bacteria Isolates}

Water (LCS), methanol (LCM), hexane (LCH) and ethylacetate (LCE) extracts of aerial parts of Lallementia canescens (LC) plant were tested on 7 standard bacterial isolates. Gram (-) of these bacteria are Pseudomonas aeruginosa American Type Culture Collection (ATCC) 27853, Klebsiella pneumoniae ATCC 700603, colistin-resistant Escherichia coli ATCC 19846, Escherichia coli ATCC 25922, Gram (+) ones Enterococcus faecalis ATCC 29212, Staphylococcus aureus 25922 Streptococcus pneumoniae is ATCC 45616. Bacterial isolates were supplied from Erzincan Mengücek Gazi Training and Research Hospital Medical Microbiology Laboratory.

\subsection{Inoculum Preparation}

Standard strains kept at $-80{ }^{\circ} \mathrm{C}$ were inoculated on $5 \%$ sheep blood medium (Biomerieux, France) and incubated at $37{ }^{\circ} \mathrm{C}$ for 16 to 18 hours. The next day, pure passage was made from the colonies grown in the sheep blood medium into a new 5\% sheep blood medium and the same procedure was repeated for the second time. 0.5 MacFarland $(1.5 \times 108 \mathrm{cfu} / \mathrm{ml})$ turbid solutions of bacterial isolates grown in the medium were adjusted in $0.9 \%$ saline and DensiCHEK Plus (Biomerieux, France) densitometer device.

\subsection{Determination of Antimicrobial Activity}

The Kirby-Bauer disk diffusion method was used to determine the antimicrobial effect of plant extracts, taking into account the recommendations of the European Committee on Antimicrobial Susceptibility Testing (EUCAST) (Bauer et al., 1966). The prepared bacterial solutions were spread on Mueller 
Table 1. Zone diameters of Lallementia canescens extracts (mean $\pm \mathrm{SD}, \mathrm{n}=3$ )

\begin{tabular}{|c|c|c|c|c|c|c|c|c|}
\hline \multirow[t]{2}{*}{ Extract } & \multirow{2}{*}{$\begin{array}{l}\text { Extract } \\
\text { Const. } \\
(\mathrm{mg} / \mathrm{ml})\end{array}$} & \multicolumn{7}{|c|}{ Zone Diameter of Standard Strains $(\mathrm{mm} \pm \mathrm{SD})$} \\
\hline & & $\mathbf{S A}$ & $\mathbf{E F}$ & SP & EC & $\begin{array}{c}\text { Col-R } \\
\text { EC }\end{array}$ & KP & PA \\
\hline \multirow[t]{3}{*}{ LCS } & 200 & - & - & - & - & - & - & - \\
\hline & 100 & - & - & - & - & - & - & - \\
\hline & 50 & - & - & - & - & - & - & - \\
\hline \multirow[t]{3}{*}{ LCM } & 200 & $9.7 \pm 0.57$ & - & $6.7 \pm 0.57$ & - & - & - & - \\
\hline & 100 & $9.7 \pm 0.57$ & - & - & - & - & - & - \\
\hline & 50 & $8.7 \pm 0.57$ & - & - & - & - & - & - \\
\hline \multirow[t]{3}{*}{ LCH } & 200 & $10.7 \pm 0.57$ & $11 \pm 1$ & - & - & - & - & - \\
\hline & 100 & $10.7 \pm 0.57$ & $11 \pm 1$ & - & - & - & - & - \\
\hline & 50 & $10 \pm 1$ & $10.7 \pm 0.57$ & - & - & - & - & - \\
\hline \multirow[t]{3}{*}{ LCE } & 200 & $12 \pm 0$ & $7.3 \pm 0.57$ & $7.3 \pm 0.57$ & - & - & - & - \\
\hline & 100 & $11.7 \pm 0.57$ & $7 \pm 0$ & $7 \pm 0$ & - & - & - & - \\
\hline & 50 & $11.7 \pm 0.57$ & $7 \pm 0$ & $6.3 \pm 0.57$ & - & - & - & - \\
\hline \multicolumn{9}{|l|}{ (+)Cont } \\
\hline AK & $30 \mu \mathrm{g} / \mathrm{ml}$ & - & - & - & $19.3 \pm 0.57$ & $18.7 \pm 0.57$ & $22.3 \pm 0.57$ & $22.7 \pm 0.57$ \\
\hline $\mathrm{E}$ & $15 \mu \mathrm{g} / \mathrm{ml}$ & $21.3 \pm 0.57$ & - & - & - & - & - & - \\
\hline VA & $5 \mu \mathrm{g} / \mathrm{ml}$ & - & $14.3 \pm 0.57$ & $25.3 \pm 0.57$ & - & - & - & - \\
\hline \multicolumn{9}{|l|}{ (-)Cont } \\
\hline $\begin{array}{l}\text { Pure } \\
\text { Water }\end{array}$ & & - & - & - & - & - & - & - \\
\hline
\end{tabular}

LCS: Lallementia canescens water extract, LCM: Lallementia canescens methanol extract, LCH: Lallementia canescens hexane extract, LCE: Lallementia canescens ethyl acetate extract, SA: Staphylococcus aureus, EF: Enterococcus faecalis, SP: Streptococcus pneumoniae, EC: Escherichia coli, Col-R EC: colistin-resistant Escherichia coli, KP: Klebsiella pneumoniae, PA: Pseudomonas aeruginosa,

-: No inhibition

\pm SD: Standard deviation, n: repitation number, AK: Amikacin, E: Erythromycin, VA: Vancomycin 
Hinton agar medium (Biomerieux, France) with the help of a cotton swab and allowed to dry for 15 minutes. Mueller Hinton Fastidious (MH-F) agar with 5\% defibrinated horse blood and $20 \mathrm{mg} / 1 \mathrm{\beta}$-NAD added was used for $S$. pneumoniae isolate. Then, $20 \mu 1$ of the stock solutions prepared with three different concentrations of each extract for each bacteria $(200 \mathrm{mg} / \mathrm{ml}, 100$ $\mathrm{mg} / \mathrm{ml}, 50 \mathrm{mg} / \mathrm{ml}$ ) were added to $6 \mathrm{~mm}$ diameter standard blank discs (Bioanalyse Turkey), and allowed to dry for 15 minutes. After the extract-impregnated discs were dried, they were placed on the surface of the medium with the help of sterile forceps and the plates were left to incubate at $37{ }^{0} \mathrm{C}$ for $16-18$ hours. At the end of the period, the diameter of the zone (zone) without bacterial growth around the discs was measured with a ruler and noted. The same procedures were repeated three times for each concentration. Vancomycin $5 \mu \mathrm{g} / \mathrm{ml}$ and Erythromycin 15 $\mu \mathrm{g} / \mathrm{ml}$ for Gram (+) bacteria and Amikacin $30 \mu \mathrm{g} / \mathrm{ml}$ disc for Gram (-) bacteria were used as positive control. Pure water was used as negative control.

\section{Resarch Findings}

As a result of the study, it was found that three different extracts were effective on three different standard bacteria. LCM extract showed $S$. aureus and $S$. pneumoniae, LCH extract displayed antimicrobial activity against $S$. aureus and $E$. faecalis, and LCE extract exhibited antimicrobial activity against $S$. aureus, E. faecalis and $S$. pneumoniae. It was observed that the effect increased or remained constant as the extract concentration increased. The highest antimicrobial activity was detected at $200 \mathrm{mg} / \mathrm{ml}$ concentration of LCE on S. aureus with a value of $12 \pm 0 \mathrm{~mm} \pm \mathrm{SD}$. LCM and LCE were found to be more effective on $S$. aureus isolate than other bacteria while LCH was most effective on $E$. faecalis with a value of $11 \pm 1 \mathrm{~mm} \pm \mathrm{SD}$. LCS was not found to be effective on any bacterial isolate. The most effective extracts on $S$. aureus were found to be LCE>LCH>LCM, on $S$. pneumoniae were LCE $>\mathrm{LCM}$, and on $E$. faecalis were $\mathrm{LCH}>\mathrm{LCE}$, respectively. While the extracts exhibited moderate antimicrobial activity compared to the positive controls, the extract closest to the positive control zone diameter of all extracts on E. faecalis was found to be LCH at $200 \mathrm{mg} / \mathrm{ml}$. The results obtained showed that none of the extracts could exhibit antimicrobial effect in E. coli, K. pneumoniae and $P$. aeruginosa isolates. The antimicrobial effect of different concentrations of plant extracts on standard bacteria is given in Table 1 .

\section{Results}

Today, there are difficulties in the treatment of multi-drug resistant bacteria, which has become a global problem. In particular, the random use of broad-spectrum antimicrobial agents increases resistance to existing agents, which increases the need for new antimicrobials. The research for antimicrobials from plants as potential sources of new antibiotics and precursor compounds is a continuing and promising alternative. Antimicrobials from plants may have therapeutic potential in the treatment of diseases caused by resistant strains. In addition, since they are of herbal origin, their side effects and toxicities are less than synthetic drugs (Abiala et al., 2016).

Lamiaceae family have been widely used as spices and natural food preservatives in the perfume industry, aromatherapy and for different medical purposes due to their aromatic and antiseptic properties (Ball et al., 1973).

Some antimicrobial studies of Lamiaceae family and Lallemantia species have been reported in the literature. A study conducted in Lebanon investigated the medicinal uses of eleven Lamiaceae species and the chemical composition of essential oils, and as a result, some essential 
oils including thymol and carvacrol were reported to have antibacterial and antifungal activity against human pathogens in vitro. (Khoury et al., 2016) .

In a study conducted in Turkey in 2016, the antimicrobial activity of the Satureja hortensis plant, which was collected from the province of Bingöl, was tested against seven pathogenic bacteria and three fungal species, and the highest antimicrobial activity was detected against $S$. aureus and B. subtilis (Alan et al., 2016).

In a study conducted in Pakistan in 2013, methanol and ethanol extracts of L. royleana (Benth.) were found to be effective against $S$. aureus, E.coli, and $P$. aeruginosa, respectively, at a concentration of $100 \mathrm{mg} / \mathrm{ml}$. However, as in our study, the water extract did not show any effect against any tested bacteria. As a result of the study, they stated that there is a concordance between the traditional use of the mentioned plant and the observed antibacterial effects (Mahmood et al., 2013).

In a study conducted in Iran in 2017, ethanol extracts of $L$. iberica seeds showed the highest inhibition zone diameter on $P$. aeruginosa $(18.3 \mathrm{~mm})$ by agar well diffusion method. As a result of this study, they concluded that medicinal plant extracts of L. iberica are suitable for use as herbal antibiotics in poultry feed and human food (Karami et al., 2017).

The only study on the antimicrobial effect of L. canescens, which is the subject of our study, was the study of Alan (Alan et al., 2019). The ethanol extract of L. canescens collected from Bitlis, Turkey was tested by agar well diffusion method on three $\mathrm{Gr}(+)$, four $\mathrm{Gr}(-)$ and three fungi. The highest antimicrobial effect was observed against $P$. aeruginosa $(17 \pm 1.15 \mathrm{~mm})$ and E.coli $(16 \pm 1.52 \mathrm{~mm})$, respectively, at a concentration of $150 \mathrm{mg} / \mathrm{ml}$, but no activity was observed against $S$. aureus and $K$. pneumoniae. They stated that L.canescens ethanol extracts are powerful antimicrobial agents due to this effect, but further studies are needed (Alan et al., 2019). In our study, unlike the aforementioned study, methanol, ethyl acetate and hexane extracts of $L$. canescens were found to be effective against $\mathrm{Gr}(+)$ bacteria, but not against $\mathrm{Gr}$ (-) bacteria. The highest antimicrobial activity was detected against $S$. aureus at $200 \mathrm{mg} / \mathrm{ml}$ concentration of LCE and against E. faecalis at $100 \mathrm{mg} / \mathrm{ml}$ concentration of LCH. The water extract did not affect any microorganisms tested. Except for the water extract, all of the other extracts were found to be effective against $S$. aureus.

These results indicate that the differences in antibacterial activities reported in the literature for all plant extracts can be attributed to different procedures followed or different geographical environment, soil composition, seasonality, physiological age of the plant, oil isolation method, as well as different bacterial strains tested. There is a need for more studies in which the mentioned variables are minimized in the investigation of the antibacterial effects of plants. As a result, it was concluded that methanol, ethyl acetate, and hexane extracts of $L$. canescens have natural antimicrobial effects and can be used as a potential source.

\section{References}

Abiala, M., Olayiwola, J., Babatunde, O., Aiyelaagbe, O., \& Akinyemi, S. (2016). Evaluation of therapeutic potentials of plant extracts against poultry bacteria threatening public health. BMC complementary and alternative medicine, 16(1), 1-8.

Alan Y, Savcı A, Koçpınar EF, Kürşat M, Topdemir S, Karataş M, Çakmak B. Antimicrobial, antioxidant and DNA protective effects and phenolic content of Lallementia canescens (L.) 
Fisch. \& C.A.Mey. and Lallementia peltata (L.) Fisch. \& C.A.Mey. Biological Diversity and Conservation, 2019; 12 (3):78-88.

Alan Y, Savcı A, Çakmak B, Kurt H. Determination of The Antimicrobial and Antioxidant Activities of Satureja hortensis Ingredients. Journal of The Institute of Natural \& Applied Sciences 21 (2) 167-177, 2016

Ball, P. W., Getliffe, F. M., Tutin, T. G., Heywood, V. H., Burges, N. A., Moore, D. M., ... \& Webb, D. A. (1973). Satureja, Acinos, Clinopodium, Calamintha. Flora Europaea, 3, 163-165.

Bauer, A.W., M.D., Kirby, W. M. M., M.D., Sherris, J. C., M.D., \& Turck, M., M.D., 1966. Antibiotic susceptibility testing by a standardized single disk method. American Journal of Clinical Pathology, 45(4), 493-496.

Baytop A, 1991.Türkiye'de Kullanılan Yabani ve Yetiştirilmiş Aromatik Bitkiler, Doğa-Tr. Journal of Pharmacy, 1(2), 76-88.

Baytop T, 1999. Türkiye'de Bitkiler ile Tedavi, İstanbul Universitesi Yayınları, 3255, Eczacılık Fakultesi, 40,İstanbul, 2. Bask1, 3, 304, 371.

Davis PH, Kit Tan MRD, 1988. Flora of Turkey and East Aegean Islands, 10, supplement University Press, Edinburgh.

Dinç M, Pınar NM, Doğu S, Yıldırımlı S, 2009. Micromorphological Studies of Lallemantia L. (Lamiaceae) Species Growing in Turkey, Acta Biologica Cracoviensia Series Botanica, 51(1), $45-54$.

Erdoğan, A. E., \& Everest, A., 2013. Antimikrobiyal ajan olarak bitki bileşenleri. Türk Bilimsel Derlemeler Dergisi, 6(2), 27-32.

Erdtman G,1945. Pollen Morphology and Plant Taxonomy IV, Svenks Botanisk Tidskrift.

Ersoy H, 2009. EDTU Herbaryumu'nda Bulunan Lamiaceae (Ballıbabgiller) Familyasının Revizyonu. Doktora Tezi, Trakya Üniversitesi Fen Bilimleri Enstitüsü, Edirne.

Güner A, Aslan S, Ekim T, Vural M, Babaç MT, (edlr.) 2012. Türkiye Bitkileri Listesi (Damarlı Bitkiler). Nezahat Gökyiğit Botanik Bahçesi ve Flora Araştırmaları Derneği Yayını. İstanbul.

Harley, R. M., Atkins, S., Budantsev, A. L., Cantino, P. D., Conn, B. J., Grayer, R., ... \& Upson, T., 2004. Labiatae. In Flowering Plants· Dicotyledons (pp. 167-275). Springer, Berlin, Heidelberg.

Hedge IC,1986. Lamiaceae of South-West Asia: diversity, distribution and endemism, Proceeding of the Royal society, 89B, 23-25, Edinburgh.

Jamzad, Z., Grayer, R. J., Kite, G. C., Simmonds, M. S., Ingrouille, M., \& Jalili, A. (2003). Leaf surface flavonoids in Iranian species of Nepeta (Lamiaceae) and some related genera. Biochemical systematics and ecology, 31(6), 587-600.

Karami, L., Ghahtan, N., \& Habibi, H. (2017). Antibacterial effect of plantago ovata and lallemantia iberica seed extracts against some bacteria. Research in Molecular Medicine, 5(3), 32-36. 
Keskin H, 2014. Hatay'da Yayılış Gösteren Teucrium polium L. (Lamiaceae) Populasyonlarında Uçucu Yağ, Flavonoid Ve Toprak Analizleri. Yüksek Lisans Tezi, Mustafa Kemal Üniversitesi Fen Bilimleri Enstitüsü, Hatay.

Khoury, M., Stien, D., Eparvier, V., Ouaini, N., \& El Beyrouthy, M. (2016). Report on the medicinal use of eleven Lamiaceae species in Lebanon and rationalization of their antimicrobial potential by examination of the chemical composition and antimicrobial activity of their essential oils. Evidence-Based Complementary and Alternative Medicine, 2016.

Li, B., Cantino, PD, Olmstead, RG, Bramley, GL, Xiang, CL, Ma, ZH, ... \& Zhang, DX, 2016. Lamiaceae'nin büyük ölçekli bir kloroplast filogenisi, alt familyal sınıflandırmasına yeni bir 1 şık tutuyor. Bilimsel raporlar,6 (1), 1-18.Li, H. W., \& Hedge, I. C. (1994). Lamiaceae. Flora of China, 17, 50-299.

Mahmood, S., Hayat, M. Q., Sadiq, A., Ishtiaq, S., Malik, S., \& Ashraf, M. (2013). Antibacterial activity of Lallemantia royleana (Benth.) indigenous to Pakistan. African journal of microbiology research, 7(31), 4006-4009.

Morteza-Semnani, K., 2006. Essential Oil Composition of Lallemantia iberica Fisch. et CA Mey. Journal of Essential Oil Research, 18(2), 164-165.

Rivera Nunez, D., Obon, D. E., \& Gastro, C. 1992. The ethnobotany of Lamiaceae of old world. Advances in Lamiaceae Science. Royal Botanical Gardens, Kew, 455-473.

Seçmen O, Gemici Y, Leblebici E, Gork, G, Bekat L, 1989.Tohumlu Bitkiler Sistematiği, Ege Universitesi Fen Fakultesi Kitaplar Serisi, Ege Universitesi Basımevi, İzmir, 276.

Tutin, T. G., Heywood, V. H., Burges, N. A., Moore, D. M., Valentine, D. H., Walters, S. M., \& Webb, D. A. (1972). Flora Europaea, Cambridge Univ. Pr., 370p. Cambridge.

Yusuf, A. L. A. N., SAVCI, A., ÇAKMAK, B., \& Havva, K. U. R. T. (2016). Determination of the antimicrobial and antioxidant activities of Satureja hortensis ingredients. Yüzüncü Yll Üniversitesi Fen Bilimleri Enstitüsü Dergisi, 21(2), 167-177. 